Thorax (1949), 4, 134.

\title{
HAEMOLYTIC ANAEMIA COMPLICATING VIRUS PNEUMONIA
}

\author{
$B Y$ \\ EDWIN BESTERMAN AND WALLACE BRIGDEN
}

From the Department of Medicine, Postgraduate Medical School of London

This case history is, we believe, the first report from Great Britain of haemolytic anaemia complicating virus pneumonia.

\section{CASE Report}

The patient was a doctor aged 35. He had been fit except for sciatica due to a prolapsed intervertebral disc. His illness began two days before admission to hospital on July 8, 1948, when he developed aching in the limbs and severe headache. He had a rigor 24 hours after the onset and his temperature was then $105^{\circ} \mathrm{F}$. There was a little serosanguineous nasal discharge at this time and a slight unproductive cough. He became disorientated and delirious. There were no contacts with a similar disease.

Physical examination on admission showed photophobia, slight neck rigidity, and moderate cervical gland enlargement. Twenty-four hours later he was mentally clearer, and a slight rustiness of the sputum had appeared. The cerebrospinal fluid chemistry was nor.ral. Haemoglobin, erythrocyte, and leucocyte counts were also normal. Sulphamezathine was started in full doses.

On July 10, 1948, radiographs showed consolidation in the right middle lobe, though there were no physical signs. The cold agglutinin titre was $1: 4$. Bronchial breathing appeared over the middle lobe on July 13. He remained febrile whilst the blood picture and urine remained normal. The erythrocyte sedimentation rate (E.S.R.) was $54 \mathrm{~mm}$. in one hour (Westergren). Sputum culture produced no specific organisms. The E.S.R. fell to $34 \mathrm{~mm}$. during the next few days and the cold agglutinin titre remained at $1: 4$. The fever steadily subsided. On July 19 when almost afebrile he appeared to be very ill. He was obviously anaemic, slightly icteric, and had hepatic tenderness. Haemoglobin was now only 8.1 g. per $100 \mathrm{ml}$. (previously $14.1 \mathrm{~g}$.). The urine showed a trace of bilirubin and no urobilin. Blood alkaline phosphatase was 8.5 units and thymol turbidity 0 . Twenty-four hours later jaundice was deeper and the liver was enlarged. The cold agglutinin titre had now sharply risen to $1: 1,000$, and it was obvious that an acute haemolytic episode had occurred.

On examination of the blood there was polychromasia, and 24 hours later $8 \%$ reticulocytes with a total of $2,350,000$ erythrocytes per c.mm. Improvement was steady after 48 hours, and on July 22 there were $2,500,000$ erythrocytes with $11 \%$ reticulocytes and 12,000 leucocytes per c.mm., with a few myelocytes. The cold agglutinin titre was now $1: 4,000$; it remained at this level for a week and fell to $1: 2,000$ on Aug. 3. Thereafter improvement continued and the blood picture returned to normal. No further haemolyses have occurred (see Fig. 1).

\section{Discussion}

Virus pneumonia is neither a new condition nor a single disease entity. In 1918 Clough and Richter described a case of atypical bronchopneumonia and in 1935 Bowen noted the radiological changes in "mild influenza," while Scadding (1937) and Reimann (1938) reported several cases of an unusual respiratory syndrome. Rainey (1939) suggested the term " atypical pneumonia," and separated the condition from other respiratory diseases, and Longcope (1940) and later Reimann (1942) suggested a virus aetiology.

Erythrocyte agglutination at temperatures lower than $37^{\circ} \mathrm{C}$. by so-called cold agglutinins has been known since the last century and has been demonstrated in numerous diseases. Clough noted cold agglutinins in her case in 1918, and in 1943 Turner, and Peterson, Ham, and Finland independently reported the association of a high cold agglutinin titre with virus pneumonia. Various series since that time quote $39 \%$ to $100 \%$ of cases showing significant titres. Young (1946) showed a titre of over $1: 128$ in $51 \%$ of cases, whilst normal controls and other respiratory disorders showed an incidence of $0.7 \%$. The level rises between the eighth and fifteenth days of the illness and usually returns to normal by the third to fifth week. Values over 1:40 are considered significant and a rising titre is confirmatory. The height of the titre appears to be related to the duration of pyrexia and extent of lung involvement. It seems probable that cold agglutinins in high titre exclude 


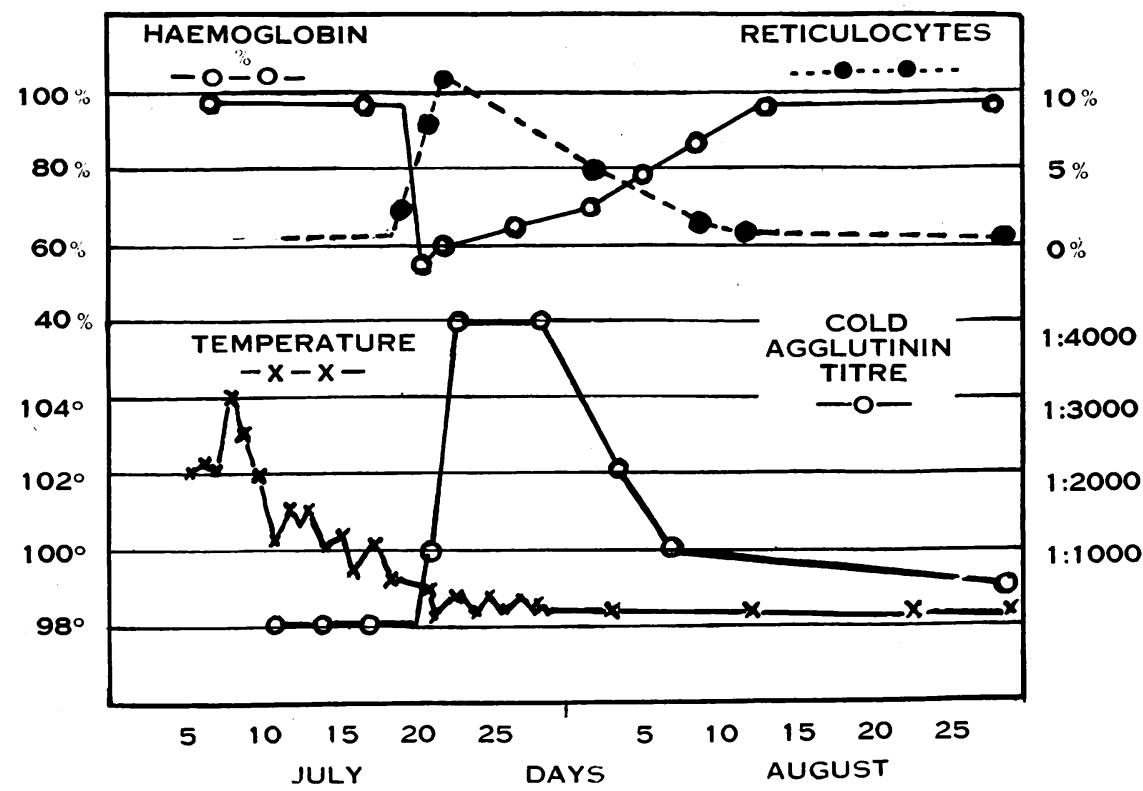

FIG. 1. globin in a few cases and bile and urobilinogen in most. The b lood picture is characteristic of haemolytic anaemia, but increased fragility of the erythrocytes has not bee $n$ demonstrated.

Nine of these patients received no sulphonamides before the development of anaemia. Sever a l continued to take a drug of this group without un toward effects. Finland and others (1945) considered the haemolysis to be due to autoa g g l u t in a tion in

bacterial pneumonia, though a negative finding does not exclude the virus group (Hegglin, 1946).

Erythrocyte fragility has been related to erythrostasis by Ham and Castle (1940), and Stats (1945) considers that the severity of haemolysis runs parallel to cold agglutinin titre in the haemolytic anaemias.

We have found 25 cases of haemolytic anaemia recorded in the literature of virus pneumonia. The case of Clough and Richter (1918) was probably the first; the urine contained urobilin and there was a high agglutination titre. In one case (Colmers and Snavely, 1947) there was a second haemolytic episode after sponge bathing with iced alcohol when the cold agglutinin titre was $1: 1280$. Peterson's observation on cold agglutinins in virus pneumonia was made in determining the blood groups of three patients having haemolytic episodes. Since 1943 several examples have been reported with and without sulphonamide therapy; however, the only large series was reported by Finland (1945) who had eleven cases in 200 patients with virus pneumonia.

A survey of these 25 cases shows that haemolysis occurs during the second or third week and the onset is often coincident with the appearance of cold agglutinins in high titre. The first signs are pallor and reddish urine, followed by jaundice and splenomegaly. The urine contained haemo- peripheral vessels. Coimers and Snavely (1947) demonstrated transient haemoglobinaemia in their patient by chilling one arm. Most of the 25 patients were severely ill and required transfusion on several occasions, and three died.

In our case a confident diagnosis of virus pneumonia was made. Acute severe haemolysis shown by jaundice, severe anaemia, and reticulocytosis occurred about the thirteenth day coinciding with a rapid rise in the cold agglutinin titre.

\section{SUMMARY}

A case of virus pneumonia was complicated by acute haemolytic anaemia, appearing at the same time as the increasing titre of cold agglutinins. The literature relating to this complication is surveyed, with particular reference to 25 similar cases reported from the United States.

\section{REFERENCES}

Bowen, A. (1935). Amer. J. Roentgenol., 34, 168.

Clough, M. C., and Richter, I. M. (1918). Bull. Johns Hopk. Hosp., 29, 86.

Colmers, R. A., and Snavely, J. G. (1947). New Engl.J. Med., 237, 505.

Finland, M., Peterson, IO. L., Allen, H. E., Samper, B. A., (1945), ibid., 24, 458; (1945), ibid., 24, 474. and Barnes, M. W. (1945). J. clin. Invest., 24, 451 ; 
Ham, T. H., and Castle, W. B. (1940). Trans. Ass. Reimann, H. A. (1938). J. Amer. med. Ass., 111, 2377. Amer. Physic., 55, 127.

Hegglin, R. (1946). Schweiz. med. Wschr., 76, 105.

Longcope, W. T. (1940). Bull. Johns Hopk. Hosp., 67, 268.

Reimann, H. A., Havens, W. P., and Price, A. H. (1942). Arch. intern. Med., 70, 513.

Peterson, O. L., Ham, T. H., and Finland, M. (1943). Science, 97, 167.

Scadding, J. G. (1937). Brit. med. J., 2, 956.

Stats, D. (1945). J. clin. Invest., 24, 33.

Turner, J. C. (1943). Nature, Lond., 151, 419.

Rainey, W. G., and Burbidge, J. R. (1939). Lancet, 59,

Young, L. E. (1946). Amer. J. med. Sci., 211, 23. 101.

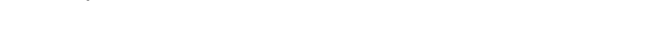

